\title{
HUBUNGAN BEBAN KERJA DAN KONSUMSI AIR MINUM DENGAN DEHIDRASI PADA PEKERJA PABRIK TAHU
}

\author{
RELATIONS BETWEEN WORKLOAD AND CONSUMPTION OF \\ DRINKING WATER WITH DEHYDRATION IN WORKERS OF TOFU \\ FACTORY
}

\author{
Afton Ilman Huda, Tjipto Suwandi \\ Departemen Keselamatan dan Kesehatan Kerja \\ Fakultas Kesehatan Masyarakat Universitas Airlangga \\ E-mail: aftonilmanh@gmail.com
}

\begin{abstract}
Dehidration can significantly impact the workers of Tahu UD Sumber Kencana Factory due to workplace climate of warm environments. In addition, high metabolism also occurs because of job duties. Workers who inadequate hydrated while working lead to dehydration. This study aims to reveal the relationship of hydration status between workload and water intake. By applying observational research with cross sectional approach, this study obtained 14 workers in tahu (tofu) and cincau production. Workload data was collected by using 10 pulse measurement method by Kilbon (1992), while water intake measurement was conducted with observation sheet of NIOSH (2011). The urine colors chart by Armstrong (1994) and Armstong (1998) was used to indicate the hydration status of workers. The results showed that workload measurement included in mild and moderate category, whereas water intake measurement was mostly indicated workers in low category. Assessing the worker's hydration status signified varied findings that were included mild, moderate, and severe category. The statistic analysis of Spearman's rank correlation showed that the workload had low relation to dehydration $(r=$ $0.094)$ and had high relation between water intake and hydration $(r=0.882)$. According to results, it can be concluded that dehydration is more likely to occur to workers with low water intake while working.
\end{abstract}

Keywords: dehydration, water intake, workload

\begin{abstract}
ABSTRAK
Dehidrasi dapat terjadi pada pekerja Pabrik Tahu UD Sumber Kencana karena iklim kerja panas yang menjadi beban panas tambahan selain panas metabolisme tubuh akibat beban kerja. Pekerja dengan konsumsi air minum yang kurang saat bekerja juga berisiko mengalami dehidrasi. Penelitian ini bertujuan untuk mempelajari hubungan beban kerja dan konsumsi air minum dengan dehidrasi. Penelitian ini merupakan penelitian observasional dengan pendekatan cross sectional. Sampel berjumlah 14 pekerja bagian produksi tahu dan cincau. Pengumpulan data beban kerja menggunakan metode pengukuran 10 denyut berdasarkan Kilbon (1992). Pengukuran konsumsi air minum dilakukan dengan lembar observasi berdasarkan NIOSH (2011). Kartu indikator warna urin berdasarkan Armstrong (1994) dan Armstrong (1998) digunakan untuk mengukur dehidrasi pada pekerja. Hasil pengukuran beban kerja termasuk dalam kategori ringan dan sedang, sedangkan pengukuran konsumsi air minum menunjukkan mayoritas pekerja termasuk dalam kategori kurang. Pengukuran dehidrasi pada pekerja menunjukkan hasil yang bervariasi yaitu kategori ringan, sedang, dan berat. Hasil analisis statistik menggunakan uji Korelasi Spearman menunjukkan beban kerja memiliki hubungan yang sangat lemah dengan dehidrasi $(\mathrm{r}=0,094)$, serta terdapat hubungan yang sangat kuat antara konsumsi air minum dengan dehidrasi $(\mathrm{r}=$ 0,882). Berdasarkan hasil tersebut, dapat disimpulkan bahwa dehidrasi cenderung terjadi pada pekerja dengan konsumsi air minum yang kurang ketika bekerja.
\end{abstract}

Kata kunci: beban kerja, dehidrasi, konsumsi air minum

\section{PENDAHULUAN}

Dehidrasi merupakan faktor penting yang harus diperhatikan. Menurut Soedirman dan Suma'mur (2014), dehidrasi merupakan kondisi dimana tubuh kehilangan cairan karena terlalu banyak berkeringat akibat terpapar panas dalam waktu yang cukup lama. Paparan panas di lingkungan kerja dapat bersumber dari proses produksi yang membutuhkan suhu tinggi seperti pemasakan biji kedelai menggunakan uap. Hal tersebut mengakibatkan iklim kerja menjadi 
panas. Tubuh manusia juga menghasilkan panas melalui proses metabolisme. Suma'mur (2009) menjelaskan bahwa kombinasi antara iklim kerja (suhu udara, kelembaban udara, kecepatan gerakan udara dan panas radiasi) dengan panas metabolisme tubuh dapat menyebabkan tekanan panas (heat stress). Pekerja yang terpapar tekanan panas menyebabkan tubuh pekerja akan merespons dengan cara mengeluarkan banyak keringat untuk mendinginkan suhu tubuh. Hal tersebut mengakibatkan tubuh kehilangan cairan secara berlebihan sehingga pekerja mengalami dehidrasi.

Hasil penelitian yang dilakukan oleh Sari (2014) menunjukkan bahwa iklim kerja panas memiliki pengaruh yang signifikan terhadap dehidrasi dan kelelahan pada tenaga kerja. Pengukuran dehidrasi yang dilakukan berdasarkan penurunan berat badan responden, menunjukkan hasil yaitu pada tenaga kerja di bagian produksi terdapat 11 responden $(73,33 \%)$ tidak mengalami dehidrasi dan 4 responden $(26,67 \%)$ mengalami dehidrasi ringan. Terdapat 5 responden $(33,33 \%)$ pada tenaga kerja yang tidak mengalami dehidrasi dan 10 responden (66,67\%) di bagian boiler yang mengalami dehidrasi ringan. Hasil uji Mann Whitney menunjukkan bahwa terdapat pengaruh antara iklim kerja panas terhadap dehidrasi $(\mathrm{p}=0,023)$.

Beban kerja juga dapat menyebabkan pekerja mengalami dehidrasi. Soeripto (2008) menjelaskan jika beban kerja seseorang meningkat maka panas metabolisme yang dihasilkan tubuh juga meningkat. Pekerja yang memiliki beban kerja berat jika berada di lingkungan kerja yang panas, maka pekerja dapat mengalami dehidrasi. Hasil penelitian Margiasih (2016) membuktikan, terdapat hubungan antara beban kerja dengan dehidrasi. Pengukuran \%CVL menunjukkan mayoritas pekerja memiliki beban kerja sedang. Hasil pengukuran dehidrasi yaitu mayoritas pekerja termasuk dalam kategori dehidrasi sedang. Analisis statistik menggunakan uji Pearson Product Moment dengan $\alpha=5 \%$ menunjukkan terdapat hubungan yang sedang antara $\% \mathrm{CVL}$ dengan dehidrasi $(p=0,16 ; r=0,423)$.

Dehidrasi dapat menyebabkan pekerja mengalami gangguan kesehatan maupun Penyakit Akibat Kerja (PAK) apabila dibiarkan secara terus menerus. Sherwood (2011) menjelaskan, dehidrasi jangka panjang dapat menyebabkan kegagalan fungsi organ seperti ginjal. Dehidrasi menyebabkan gangguan keseimbangan cairan tubuh akibat terlalu banyak berkeringat. Konsumsi air minum yang kurang pada penderita dehidrasi menyebabkan tubuh menyeimbangkan diri dengan cara mengambil air dari darah. Hal tersebut mengakibatkan darah menjadi kental sehingga memperberat kerja ginjal dalam menyaring darah. Darah yang mengental jika dibiarkan secara terus menerus dapat menyebabkan kerusakan pada ginjal, oleh karena itu salah satu cara pencegahan dehidrasi yaitu mengonsumsi air minum dalam jumlah yang cukup. Suma'mur (2009) menyebutkan, di tempat kerja dengan iklim kerja yang panas harus disediakan air minum bagi pekerja dalam jumlah yang cukup sebagai upaya preventif terhadap dehidrasi.

Hasil penelitian Agustin (2012) pada pekerja di home industry Kerupuk Santoso menunjukkan sebagian pekerja mengonsumsi air $<200 \mathrm{cc}$ per menit selama bekerja, dengan rata-rata konsumsi air minum hanya $100 \mathrm{cc}$ per menit. Pengukuran Nilai Ambang Batas (NAB) iklim kerja di titik I $\left(32,3^{\circ} \mathrm{C}\right)$ dan II $\left(30,6^{\circ} \mathrm{C}\right)$ melebihi NAB untuk pekerjaan dengan beban kerja sedang yaitu $28^{\circ} \mathrm{C}$. Hasil penelitian tersebut menunjukkan pekerja belum memiliki kebiasaan konsumsi air minum dalam jumlah yang cukup padahal iklim kerja melebihi NAB sehingga dapat menyebabkan gangguan kesehatan seperti dehidrasi.

Berdasarkan uraian tersebut, perlu dilakukan penelitian mengenai hubungan iklim kerja, beban kerja, dan konsumsi air minum dengan dehidrasi. Namun, iklim kerja tidak diteliti dalam penelitian ini karena seluruh proses produksi di UD Sumber Kencana berada dalam satu ruangan sehingga tidak terdapat variasi data iklim kerja, sehingga rumusan masalah dari penelitian ini adalah bagaimana hubungan antara beban kerja dan konsumsi air minum dengan tingkat dehidrasi. Tujuan penelitian ini yaitu menganalisis hubungan beban kerja dan konsumsi air minum dengan dehidrasi pada pekerja Pabrik Tahu UD Sumber Kencana Surabaya.

\section{METODE}

Penelitian ini termasuk jenis penelitian observasional, dengan pendekatan cross sectional karena dilaksanakan pada waktu tertentu. Penelitian ini juga termasuk jenis penelitian analitik jika ditinjau berdasarkan analisis data yang dilakukan. Ditinjau dari tempat pelaksanaan, penelitian ini termasuk penelitian lapangan. Lokasi pengumpulan data penelitian yaitu di bagian produksi tahu dan cincau Pabrik Tahu UD Sumber Kencana yang 
beralamatkan di Jalan Dinoyo nomor 81-83 A RT 03 RW 03 Kelurahan Keputran, Surabaya. Penelitian ini dilakukan sejak Oktober 2015 sampai Mei 2016.

Populasi dari penelitian ini yaitu seluruh pekerja yang berjumlah 16 orang. Penentuan sampel dilakukan berdasarkan 3 kriteria inklusi. Kriteria pertama yaitu pekerja yang bekerja di bagian produksi tahu dan cincau Pekerjaan di bagian tersebut membutuhkan suhu yang tinggi dan menyebabkan iklim kerja panas sehingga pekerja membutuhkan konsumsi air minum yang cukup untuk mencegah dehidrasi. Kriteria kedua yaitu pekerja yang memiliki gejala dehidrasi berdasarkan Wilmore (2007) dalam Puspita (2015) yaitu mulut kering, jantung berdebar-debar, pusing, kram otot atau nyeri, lelah, kulit menjadi kurang elastis dan badan selalu merasa kepanasan. Kriteria ketiga yaitu pekerja yang bekerja pada pukul 10.00-14.00 sesuai dengan waktu kerja Pabrik Tahu UD Sumber Kencana. Observasi awal dan skrining yang telah dilakukan menunjukkan, jumlah sampel yang memenuhi ketiga kriteria inklusi tersebut sebanyak 14 pekerja.

Terdapat dua variabel dalam penelitian ini yaitu variabel independen dan variabel dependan. Beban kerja dan konsumsi air minum merupakan variabel independen, sedangkan variabel dependen penelitian ini yaitu dehidrasi pada pekerja. Pengumpulan data beban kerja pada responden dilakukan dengan metode 10 denyut berdasarkan Kilbon (1992) dalam Tarwaka (2004), yaitu dengan mengukur 10 denyut nadi kerja dan nadi istirahat menggunakan stopwatch. Pengukuran Denyut Nadi Kerja (DNK) dilakukan sebanyak 4 kali selama pekerjaan berlangsung untuk mengurangi efek bias. Hasil pengukuran kemudian dihitung menggunakan rumus denyut nadi per menit, sehingga dapat dikategorikan. Terdapat lima kategori beban kerja berdasarkan Suma'mur (2009) yaitu beban kerja ringan, sedang, berat, sangat berat, dan sangat berat sekali. Jika beban kerja semakin berat maka denyut nadi per menit pada pekerja juga semakin meningkat.

Pengukuran konsumsi air minum dilakukan menggunakan lembar observasi yang didasarkan dari ketentuan NIOSH (2011) yaitu pekerja yang bekerja di lingkungan kerja panas harus meminum air minimal 150-200 cc setiap 15 sampai 20 menit sekali. Observasi dilakukan dengan cara peneliti menyediakan air minum kemasan gelas (240 cc). Responden dipersilahkan untuk meminum air tersebut secara bebas selama bekerja. Jumlah air yang harus di minum sesuai ketentuan yaitu
1.800-2.400 cc selama bekerja mulai pukul 10.00 sampai 14.00. Terdapat tiga kategori konsumsi air minum pada pekerja yaitu lebih, cukup, dan kurang. Selain observasi, kuesioner juga digunakan untuk mendapatkan data tentang konsumsi air minum.

Dehidrasi pada pekerja diukur dengan mengambil spesimen urin sesaat setelah bekerja dan dibandingkan dengan kartu indikator warna urin berdasarkan Armstrong (1994) dan Armstrong (1998). Spesimen urin diambil dengan cara peneliti menyediakan gelas kaca sebagai wadah. Pekerja diminta untuk kencing dan menaruh spesimen urin secukupnya ke dalam gelas kaca, sehingga peneliti dapat membandingkan dengan kartu indikator warna urin di tempat yang terang. Terdapat 8 indikator warna dalam kartu tersebut dengan ketentuan yaitu semakin tinggi tingkat dehidrasi pekerja maka semakin pekat warna urinnya. Hasil pengukuran kemudian dicatat dan dikategorikan dalam 3 kriteria yaitu dehidrasi ringan, sedang, dan berat.

Data primer diperoleh dengan cara pengukuran beban kerja dan dehidrasi pada responden. Kuesioner untuk memperoleh data pendukung tentang konsumsi air minum dan karakteristik responden. Observasi dilakukan guna mendapat data konsumsi air minum. Data sekunder diperoleh dari website Pabrik Tahu. Data yang diperoleh yaitu gambaran umum pabrik, sistem manajemen atau pembagian tugas di pabrik, bahan baku, alat, serta proses produksi tahu dan cincau.

Data penelitian yang diperoleh kemudian dianalisis dengan uji statistik untuk mengetahui hubungan antar variabel. Berdasarkan tujuan dari penelitian, skala data, dan distribusi data, uji yang digunakan yaitu uji Korelasi Spearman. Uji tersebut digunakan dalam menganalisis koefisien korelasi (r) sehingga dapat ditentukan kuat hubungan antara beban kerja dan konsumsi air minum dengan dehidrasi.

\section{HASIL}

Hasil kuesioner terhadap 14 responden menunjukkan, terdapat 11 responden $(78,5 \%)$ yang berusia diatas 40 tahun dan 3 responden $(21,5 \%)$ berusia dibawah 40 tahun. Responden dengan usia tertua yaitu 59 tahun, sedangkan usia termuda responden yaitu 27 tahun. Hasil kuesioner berdasarkan jenis kelamin menunjukkan, terdapat 11 responden $(78,5 \%)$ laki-laki dan 3 responden $(21,5 \%)$ perempuan. Terdapat 8 responden $(57,2 \%)$ dengan masa kerja lebih dari 13 tahun, dan 6 
Tabel 1. Hasil Pengukuran Iklim Kerja di Pabrik Tahu UD Sumber Kencana, Mei 2016

\begin{tabular}{lccccccc}
\hline Lokasi Pengukuran & $\begin{array}{c}\text { Jam } \\
(\mathbf{W I B})\end{array}$ & $\begin{array}{c}\text { Sb } \\
\left({ }^{\circ} \mathbf{C}\right)\end{array}$ & $\begin{array}{c}\text { Sk } \\
\left({ }^{\circ} \mathbf{C}\right)\end{array}$ & $\mathbf{S g}\left({ }^{\circ} \mathbf{C}\right)$ & $\begin{array}{c}\mathbf{I S B B} \\
\left({ }^{\circ} \mathbf{C}\right)\end{array}$ & $\begin{array}{c}\mathbf{R H} \\
(\mathbf{\%})\end{array}$ & Keterangan \\
\hline Pemasakan Cincau & 10.04 & 30,6 & 33,5 & 36,2 & 32,3 & 71 & Cuaca normal \\
Pemasakan Tahu & 10.11 & 30,2 & 33,4 & 35,4 & 31,5 & 64 & Cuaca normal \\
Operator Mesin Uap & 10.45 & 29,9 & 34,6 & 38,7 & 32,5 & 57 & Cuaca normal \\
Cuci Kedelai & 11.19 & 29,1 & 33,6 & 35,3 & 30,8 & 68 & Cuaca normal \\
Giling Kedelai & 11.26 & 29,4 & 34,4 & 35,1 & 31,0 & 62 & Cuaca normal \\
Pemotongan Tahu & 11.32 & 29,6 & 34,4 & 34,9 & 31,1 & 63 & Cuaca normal \\
\hline
\end{tabular}

responden $(42,8 \%)$ memiliki masa kerja antara 4-12 tahun. Hasil kuesioner terhadap responden juga menunjukkan bahwa tidak ada waktu istirahat, namun berdasarkan hasil wawancara menunjukkan responden dapat beristirahat disela pekerjaan dengan cara duduk dan meminum air putih.

Pengukuran iklim kerja di lakukan di 6 titik yaitu bagian pemasakan cincau, pemasakan tahu, operator mesin uap, cuci kedelai, giling kedelai, dan pemotongan tahu. Penentuan titik tersebut didasarkan pada tiap bagian produksi, namun seluruh kegiatan berada pada satu ruangan tanpa adanya pembatas antar bagian produksi dan menyebabkan tidak adanya variasi data iklim kerja. Pengukuran dilakukan pada tanggal 12 Mei 2016. Hasil pengukuran iklim kerja menggunakan alat Heat Stress Apparatus Merk Quest Tipe Quest Temp 36 menunjukkan bahwa Suhu Kering (Sk) tertinggi yaitu $34,6^{\circ} \mathrm{C}$ dan terendah yaitu $33,4{ }^{\circ} \mathrm{C}$. Hasil pengukuran pada Tabel 1 menunjukkan bahwa suhu ruangan/suhu kering (Sk) seluruh titik pengukuran melebihi ketentuan suhu nyaman untuk bekerja berdasarkan Suma'mur (2009) yaitu $24-26{ }^{\circ} \mathrm{C}$.

\section{BEBAN KERJA}

Pengukuran beban kerja dilakukan dengan metode 10 denyut berdasarkan Kilbon (1992). Pengukuran Denyut Nadi Istirahat (DNI) dilakukan ketika pekerjaan belum dimulai yaitu pada pukul 09.45, sedangkan pengukuran Denyut Nadi Kerja (DNK) dilakukan pukul 11.00, 12.00, 13.00, dan 14.00. Pengukuran dilakukan menggunakan stopwatch dan data yang diperoleh dicatat di lembar pengukuran untuk dianalisis lebih lanjut. Hasil pengukuran pada Tabel 2 menunjukkan data
10 denyut nadi pada responden. Sebagai contoh, responden 1 memiliki rata-rata waktu 5,39 detik ketika 10 denyut diukur pada saat bekerja (DNK). Hasil pengukuran tersebut kemudian dihitung menggunakan rumus denyut nadi per menit berdasarkan Kilbon (1992) dan Tarwaka (2004):

\section{$\frac{\text { Denyut }}{\text { Hanit }}=\frac{10 \text { Denyut }}{\text { Walth Pathibmpan }} \times 60$}

Misal, untuk mengetahui rata-rata jumlah denyut nadi per menit ketika responden 1 melakukan pekerjaan, maka perhitungan yang dilakukan adalah:

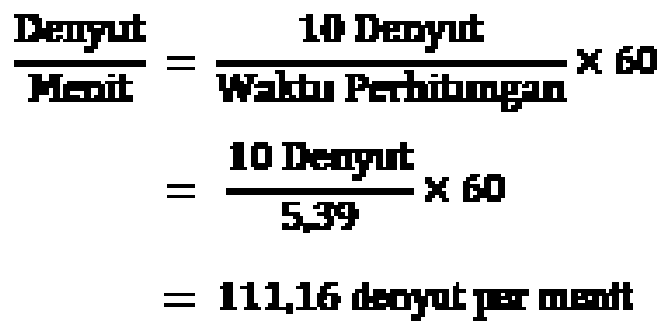

Hasil perhitungan 10 denyut pada responden menggunakan rumus denyut nadi per menit dapat dilihat pada Tabel 3. Hasil perhitungan rata-rata DNK per menit kemudian dikategorikan dengan kriteria beban kerja berdasarkan denyut nadi per menit menurut Suma'mur (2009) untuk mengetahui beban kerja pada responden. Terdapat 5 kategori beban kerja yaitu beban kerja ringan (75-100 denyut per menit), beban kerja sedang (100-125 denyut per menit), beban kerja berat (125-150 denyut per menit), beban kerja sangat berat (150-175 denyut per menit), dan beban kerja sangat berat sekali (>175 denyut per menit). Distribusi responden berdasarkan 
Tabel 2. Hasil Pengukuran Denyut Nadi Istirahat (DNI) dan Denyut Nadi Kerja (DNK) di Pabrik Tahu UD Sumber Kencana

\begin{tabular}{ccccccc}
\hline \multirow{2}{*}{ Responden } & DNI (detik) & \multicolumn{6}{c}{ DNK (detik) } & $\begin{array}{c}\text { Rata-rata DNK } \\
\text { (detik) }\end{array}$ \\
\cline { 3 - 7 } & 8 & $\mathbf{1}$ & $\mathbf{2}$ & $\mathbf{3}$ & $\mathbf{4}$ & 5,39 \\
2 & 5,14 & 5,06 & 5,19 & 6,2 & 5,27 \\
3 & 6,65 & 5,72 & 5,6 & 4,45 & 5,33 & 5,35 \\
4 & 6,82 & 5,29 & 5,86 & 4,65 & 5,63 & 6,39 \\
5 & 7,25 & 6,14 & 6,36 & 6,43 & 6,65 & 5,78 \\
6 & 7,92 & 7,28 & 5,56 & 4,46 & 5,82 & 6,12 \\
7 & 7,2 & 6,16 & 5,95 & 5,93 & 6,43 & 5,92 \\
8 & 7,72 & 5,42 & 5,99 & 5,62 & 6,66 & 5,52 \\
9 & 7,86 & 5,26 & 4,93 & 5,78 & 6,12 & 6,34 \\
10 & 7,77 & 5,37 & 6,96 & 5,82 & 7,22 & 6,35 \\
11 & 8,69 & 6,56 & 7,02 & 5,68 & 6,14 & 5,57 \\
12 & 6,52 & 6,06 & 5,18 & 5,17 & 5,88 & 6,68 \\
13 & 8,25 & 6,79 & 6,64 & 6,85 & 6,46 & 7,40 \\
14 & 8,52 & 7,71 & 6,67 & 6,95 & 8,29 & 6,70 \\
\hline
\end{tabular}

Tabel 3. Hasil Perhitungan Denyut Nadi Per Menit Berdasarkan Kilbon (1992)

\begin{tabular}{|c|c|c|c|c|c|c|}
\hline \multirow{2}{*}{ Responden } & \multirow{2}{*}{ DNI (detik) } & \multicolumn{4}{|c|}{ DNK (denyut/menit) } & \multirow{2}{*}{$\begin{array}{l}\text { Rata-rata DNK } \\
\text { (denyut/menit) }\end{array}$} \\
\hline & & 1 & 2 & 3 & 4 & \\
\hline 1 & 8 & 116,73 & 118,58 & 115,61 & 96,77 & 111,16 \\
\hline 2 & 6,65 & 104,90 & 107,14 & 134,83 & 112,57 & 113,74 \\
\hline 3 & 6,82 & 113,42 & 102,39 & 129,03 & 106,57 & 111,99 \\
\hline 4 & 7,25 & 97,72 & 94,34 & 93,31 & 90,23 & 93,82 \\
\hline 5 & 7,92 & 82,42 & 107,91 & 134,53 & 103,09 & 103,81 \\
\hline 6 & 7,2 & 97,40 & 100,84 & 101,18 & 93,31 & 98,08 \\
\hline 7 & 7,72 & 110,70 & 100,17 & 106,76 & 90,09 & 101,31 \\
\hline 8 & 7,86 & 121,70 & 103,81 & 98,04 & 108,65 & 114,07 \\
\hline 9 & 7,77 & 111,73 & 86,21 & 103,09 & 83,10 & 94,60 \\
\hline 10 & 8,69 & 91,46 & 85,47 & 105,63 & 97,72 & 94,49 \\
\hline 11 & 6,52 & 99,01 & 115,83 & 116,05 & 102,04 & 107,67 \\
\hline 12 & 8,25 & 88,37 & 90,36 & 87,59 & 92,88 & 89,75 \\
\hline 13 & 8,52 & 77,82 & 89,96 & 86,33 & 72,38 & 81,03 \\
\hline 14 & 7,86 & 83,33 & 103,63 & 81,74 & 92,59 & 89,52 \\
\hline
\end{tabular}

kategori beban kerja menurut Suma'mur (2009) pada Tabel 4.

Hasil perhitungan pada Tabel 4 dapat disimpulkan bahwa terdapat 7 responden $(50 \%)$ dengan kategori beban kerja ringan (rata-rata Denyut Nadi Kerja antara 75-100 denyut per menit) dan 7 responden (50\%) dengan kategori beban kerja sedang (rata-rata Denyut Nadi Kerja antara 100-125 
denyut per menit). Tidak terdapat responden dengan kategori beban kerja berat, sangat berat, dan sangat berat sekali.

\section{Konsumsi Air Minum}

Hasil kuesioner menunjukkan bahwa pemilik Pabrik Tahu UD Sumber Kencana tidak menyediakan air minum bagi responden selama bekerja, sehingga responden harus membawa air minum sendiri dari rumah. Hasil wawancara dengan responden menunjukkan, air minum yang biasa dibawa dari rumah yaitu air putih yang disimpan dalam botol plastik kemasan 1,5 liter serta terdapat salah seorang responden yang berjualan air minum di dekat Pabrik Tahu sehingga responden dapat membeli minum apabila tidak membawa air dari rumah.

Pengukuran konsumsi air minum dilakukan dengan cara observasi dan dinyatakan dalam satuan cc. Air minum dalam kemasan gelas $(240 \mathrm{cc})$ disediakan oleh peneliti dan responden dipersilahkan untuk meminum air tersebut secara bebas. Observasi dilakukan selama pekerjaan berlangsung, yaitu mulai pukul 10.00 sampai 14.00. Kategori konsumsi air minum responden didasarkan ketentuan NIOSH (2011), yaitu air yang harus diminum pekerja yang terpapar panas selama bekerja sebanyak 150-200 cc tiap 15 sampai 20 menit sekali. Berdasarkan ketentuan tersebut, jumlah air yang harus dikonsumsi responden selama 4 jam kerja yaitu $1.800-2.400$ cc.

Terdapat 3 kategori konsumsi air minum pada responden yaitu lebih, cukup, dan kurang. Kategori yang pertama yaitu lebih, jika jumlah air minum yang dikonsumsi responden $>150-200$ cc tiap 15 sampai 20 menit sekali $(>1.800-2.400$ cc selama bekerja). Kategori kedua yaitu cukup,

Tabel 4. Distribusi Responden Berdasarkan Beban Kerja di Pabrik Tahu UD Sumber Kencana Tahun 2016

\begin{tabular}{lcc}
\hline \multicolumn{1}{c}{ Beban Kerja } & Frekuensi & Persentase (\%) \\
\hline Ringan & 7 & 50 \\
Sedang & 7 & 50 \\
Berat & 0 & 0 \\
Sangat Berat & 0 & 0 \\
Sangat Berat Sekali & 0 & 0 \\
\hline Jumlah & 14 & 100 \\
\hline
\end{tabular}

jika jumlah air minum yang dikonsumsi responden antara 150-200 cc tiap 15 sampai 20 menit sekali (antara 1.800-2.400 cc selama bekerja). Kategori ketiga yaitu kurang, jika jumlah air minum yang dikonsumsi responden $<150-200$ cc tiap 15 sampai 20 menit sekali $(<1.800-2.400$ cc selama bekerja). Distribusi responden berdasarkan konsumsi air minum dapat dilihat dalam Tabel 5.

Hasil observasi pada Tabel 5 dapat disimpulkan bahwa terdapat 5 responden $(35,71 \%)$ yang mengonsumsi air minum dalam jumlah yang cukup yaitu antara 1.800-2.400 cc selama 4 jam bekerja. Sedangkan, 9 responden lain $(64,29 \%)$ mengonsumsi air minum dalam jumlah yang kurang dari 1.800-2.400 cc selama 4 jam bekerja.

\section{Dehidrasi}

Pengukuran dehidrasi pada responden dilakukan sesaat setelah pekerjaan selesai dengan cara mengambil spesimen urin dan dibandingkan dengan kartu indikator warna urin berdasarkan Armstrong (1994) dan Armstrong (1998). Peneliti menyediakan gelas kaca sebagai tempat untuk responden menaruh spesimen urin. Terdapat 3 kategori dehidrasi berdasarkan 8 indikator warna urin yaitu dehidrasi ringan, sedang, dan berat. Dehidrasi ringan terjadi apabila warna urin responden termasuk dalam indikator nomor 1, 2, dan 3. Kategori dehidrasi sedang yaitu jika warna urin responden termasuk

Tabel 5. Distribusi Responden Berdasarkan Konsumsi Air Minum di Pabrik Tahu UD Sumber Kencana Tahun 2016

\begin{tabular}{lcc}
\hline Konsumsi Air Minum & Frekuensi & $\begin{array}{c}\text { Persentase } \\
(\%)\end{array}$ \\
\hline Lebih & 0 & 0 \\
Cukup & 5 & 35,71 \\
Kurang & 9 & 64,29 \\
\hline Total & 14 & 100 \\
\hline
\end{tabular}

dalam indikator nomor 4, 5, dan 6. Responden dinyatakan mengalami dehidrasi berat apabila warna urin termasuk dalam indikator nomor 7 dan 8. Pengukuran menggunakan metode warna urin merupakan salah satu cara yang sangat akurat dalam melihat indikasi adanya dehidrasi jangka pendek pada responden karena metode tersebut memiliki nilai sensitivitas sampai dengan $80 \%$. Distribusi responden berdasarkan dehidrasi pada Tabel 6 . 


\section{1}
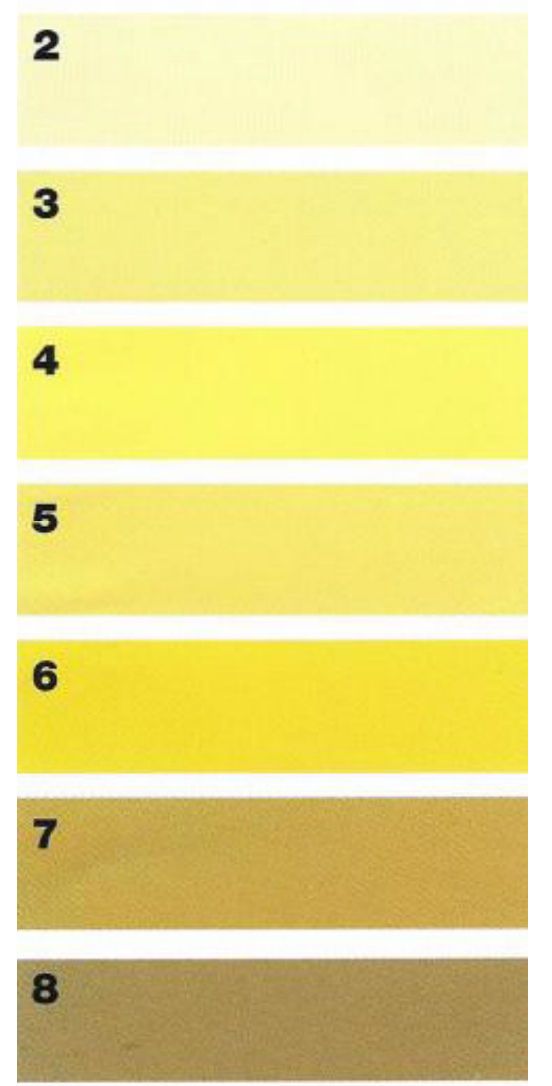

Gambar 1. Kartu Indikator Warna Urin

Sumber: Armstrong (1994) dan Armstrong (1998)

Distribusi responden pada Tabel 6 menunjukkan kategori dehidrasi pada responden bervariasi. Responden yang mengalami dehidrasi ringan dengan indikator warna urin antara 1 sampai 3 , sebanyak 5 orang $(35,71 \%)$. Responden yang mengalami dehidrasi sedang dengan indikator warna urin antara 4 sampai 6 , sebanyak 5 orang $(35,71 \%)$. Sedangkan responden yang memiliki dehidrasi berat dengan indikator warna urin nomor 7 dan 8 , sebanyak 4 orang $(28,58 \%)$.

\section{Hubungan Beban Kerja dengan Dehidrasi}

Hasil pengukuran beban kerja yang telah dilakukan menunjukkan, terdapat dua kategori beban kerja pada responden yaitu ringan dan sedang. Pengukuran dehidrasi pada responden menunjukkan hasil yang bervariasi yaitu dehidrasi ringan, sedang,
Tabel 6. Distribusi Responden Berdasarkan Dehidrasi di Pabrik Tahu UD Sumber Kencana Tahun 2016

\begin{tabular}{lcc}
\hline Tingkat Dehidrasi & Frekuensi & Persentase (\%) \\
\hline Ringan & 5 & 35,71 \\
Sedang & 5 & 35,71 \\
Berat & 4 & 28,58 \\
\hline Total & 14 & 100 \\
\hline
\end{tabular}

dan berat. Analisis hasil pengukuran beban kerja dengan dehidrasi dilakukan menggunakan uji Korelasi Spearman untuk mengetahui koefisien korelasi sehingga dapat ditentukan kuat hubungan antara kedua variabel tersebut. Hasil uji yang telah dilakukan menunjukkan koefisien korelasi $(\mathrm{r})=$ 0,094. Hasil tersebut menunjukkan koefisien korelasi yang didapat mendekati 0 sehingga dapat ditarik kesimpulan bahwa terdapat hubungan yang sangat rendah/lemah sekali antara beban kerja dengan dehidrasi pada pekerja di Pabrik Tahu UD Sumber Kencana.

\section{Hubungan Konsumsi Air Minum dengan Dehidrasi}

Hasil penelitian menunjukkan, konsumsi air minum pada responden termasuk dalam kategori cukup dan kurang. Responden juga mengalami dehidrasi ringan, sedang, dan berat. Hasil analisis data konsumsi air minum dengan dehidrasi menggunakan uji Korelasi Spearman menunjukkan nilai koefisien korelasi $(r)=0,882$. Berdasarkan hasil uji tersebut, koefisien korelasi (r) yang diperoleh mendekati 1 sehingga dapat ditarik kesimpulan yaitu adanya hubungan yang sangat kuat antara konsumsi air minum dengan dehidrasi.

\section{PEMBAHASAN}

\section{Beban Kerja}

Pengukuran beban kerja pada 14 responden di Pabrik Tahu UD Sumber Kencana menunjukkan hasil yaitu 7 responden (50\%) termasuk dalam kategori beban kerja ringan dan 7 responden $(50 \%)$ dalam kategori beban kerja sedang. Tidak terdapat responden yang memiliki beban kerja berat, sangat berat, dan sangat berat sekali. Hal tersebut dapat 
disebabkan waktu kerja di Pabrik Tahu UD Sumber Kencan yang hanya 4 jam per hari sehingga masih dibawah ketentuan berdasarkan Undang-Undang Republik Indonesia Nomor 13 Tahun 2003 tentang Ketenagakerjaan, yaitu 8 jam per hari atau 40 jam per minggu.

Tarwaka (2004) menyebutkan, faktor eksternal seperti waktu kerja dapat mempengaruhi beban kerja. Semakin meningkat waktu kerja maka beban kerja juga semakin meningkat. Begitu pula sebaliknya, pengurangan waktu kerja dapat menurunkan beban kerja. Suma'mur (2009) juga menjelaskan, peningkatan waktu kerja melebihi kemampuan lama kerja menyebabkan penurunan kemampuan kerja sehingga efisiensi dan efektivitas menurun serta produktivitas kerja yang tidak optimal. Penurunan kemampuan kerja tersebut merupakan akibat dari naiknya beban kerja ketika waktu kerja diperpanjang, sehingga dapat disimpulkan bahwa ringan dan sedangnya beban kerja pada responden disebabkan oleh waktu kerja di Pabrik Tahu UD Sumber Kencana yang masih berada di bawah 8 jam per hari atau 40 jam per minggu.

Penelitian yang dilakukan Maharja (2015) mengenai analisis tingkat kelelahan kerja berdasarkan beban kerja fisik perawat di Instalasi Rawat Inap RSU Haji Surabaya menunjukkan, responden dengan beban kerja ringan yang mengalami kelelahan kerja tingkat ringan sebanyak 5 orang $(71,4 \%)$ dan 2 orang $(28,6 \%)$ mengalami kelelahan kerja tingkat sedang. Responden dengan beban kerja sedang yang mengalami kelelahan kerja ringan sebanyak 5 orang $(25,0 \%)$ dan 12 orang $(60,0 \%)$ mengalami kelelahan kerja tingkat sedang. Analisis statistik menggunakan uji korelasi Spearman menunjukkan nilai koefisien korelasi sebesar 0,428 yang berarti, beban kerja memiliki hubungan yang kuat dan searah kelelahan kerja. Hasil tersebut menunjukkan semakin berat beban kerja responden, maka kelelahan kerja yang dialami responden juga semakin berat.

\section{Konsumsi Air Minum}

Hasil observasi konsumsi air minum menunjukkan, terdapat 5 responden $(35,71 \%)$ yang mengonsumsi air dalam jumlah yang cukup dan 9 responden $(64,29 \%)$ yang mengonsumsi air dalam jumlah yang kurang. Hasil wawancara dengan responden menunjukkan tidak ada pengaturan waktu istirahat di Pabrik Tahu UD Sumber Kencana, namun berdasarkan observasi awal ketika jam kerja menunjukkan responden biasanya meminum air saat beristirahat di sela-sela pekerjaan. Soedirman dan Suma'mur (2014) menjelaskan, waktu istirahat bagi pekerja yang terpapar panas sangatlah penting sebagai upaya pencegahan terjadinya heat related disease seperti dehidrasi. Pengaturan waktu kerja dan waktu istirahat dapat dihitung menggunakan formula Wet-Globe Temperature Index (WBGT) atau Indeks Suhu Basah Bola (ISBB), sehingga dapat ditentukan presentase waktu istirahat setiap jamnya untuk beban kerja ringan, sedang dan berat.

Hasil penelitian menunjukkan masih terdapat 9 responden yang masih memiliki kebiasaan konsumsi air minum dibawah kriteria NIOSH (2011), padahal hasil pengukuran suhu ruangan di pabrik tersebut melebihi ketentuan suhu nyaman untuk bekerja berdasarkan Suma'mur (2009) sehingga responden seharusnya mengonsumsi 150-200 cc air minum tiap 15-20 menit sekali. Penelitian yang dilakukan Fajrin (2014) mengenai faktor yang berhubungan dengan keluhan kesehatan akibat tekanan panas pada pekerja instalasi laundry Rumah Sakit di kota Makassar menunjukkan, sebanyak 23 (38,3\%) dari 60 responden memiliki kebiasaan mengonsumsi air pada rentang 1,00-1,25 liter selama bekerja. Hasil penelitian mengenai keluhan akibat tekanan panas menunjukkan sebanyak 60 responden (100\%) mengalami keluhan berupa berkeringat. Analisis data konsumsi air minum dengan keluhan akibat tekanan panas menggunakan uji korelasi Spearman menunjukkan nilai $p=0,000$. Nilai $p$ tersebut lebih kecil dari 0,05 sehingga dapat disimpulkan bahwa konsumsi air minum berhubungan dengan keluhan akibat tekanan panas pada pekerja.

Hasil kuesioner menunjukkan terdapat 11 responden yang memiliki kebiasaan konsumsi air minum saat haus saja, sedangkan 3 responden memiliki kebiasaan konsumsi air minum sewaktu-waktu. Hal tersebut kurang sesuai dengan kriteria konsumsi air minum yang benar berdasarkan NIOSH (2011). Soeripto (2008) menyebutkan, ketika pekerja sedang bekerja di tempat yang panas, pekerja harus didorong untuk meminum air dalam jumlah yang cukup sehingga pemilik Pabrik Tahu UD Sumber Kencana sebaiknya mengharuskan responden untuk mengonsumsi air sebanyak 1 gelas (150-200 cc) setiap 15-20 menit sekali (> 1.8002.400 cc selama 4 jam kerja).

Konsumsi air minum yang kurang pada responden juga dapat disebabkan karena air minum tidak disediakan oleh pemilik pabrik, sehingga responden harus membawa sendiri dari rumah. Soeripto (2008) menjelaskan, pekerja yang terpapar panas harus disediakan air minum dengan ketentuan 
yaitu jumlah yang cukup sesuai kebutuhan (150-200 cc air minum tiap 15-20 menit sekali) dan disimpan dalam tempat yang dingin, serta ditempatkan tidak terlalu jauh dari lingkungan kerja sehingga mudah diambil. Pemilik pabrik seharusnya menyediakan air minum sesuai ketentuan tersebut untuk memenuhi kebutuhan air minum pekerja selama melakukan pekerjaan.

\section{Dehidrasi}

Hasil pengukuran dehidrasi menunjukkan responden yang mengalami dehidrasi ringan sebanyak 5 pekerja $(35,71 \%), 5$ responden $(35,71 \%)$ mengalami dehidrasi sedang, dan 4 responden (28,58\%) mengalami dehidrasi berat. Pekerja yang berada di lingkungan dengan suhu ruangan melebihi suhu nyaman untuk bekerja seperti di Pabrik Tahu UD Sumber Kencana, mudah mengalami dehidrasi. Sesuai hukum Hooke dalam Soedirman dan Suma'mur (2014), pekerja akan kehilangan keringat secara meningkat ketika bekerja di lingkungan yang panas. Hal tersebut menyebabkan hilangnya cairan tubuh akibat evaporasi atau berkeringat, sehingga meningkatkan risiko terjadinya dehidrasi.

Penelitian yang dilakukan Sari (2014) membuktikan bahwa terdapat pengaruh antara iklim kerja terhadap dehidrasi pada pekerja di PT Albasia Sejahtera Mandiri Semarang. Hasil pengukuran iklim kerja di bagian produksi $\left(27^{\circ} \mathrm{C}\right)$ tidak melebihi Nilai Ambang Batas (NAB), sedangkan iklim kerja di bagian boiler $\left(32^{\circ} \mathrm{C}\right)$ melebihi NAB yang diperkenankan. Pengukuran dehidrasi pada responden menggunakan metode penurunan berat badan menunjukkan, pekerja bagian produksi yang tidak mengalami dehidrasi sebanyak 11 responden $(73,33 \%)$ dan pekerja yang mengalami dehidrasi ringan sebanyak 4 responden $(26,67 \%)$. Hasil analisis menggunakan uji Mann Whitney menunjukkan nilai $\mathrm{p}=0.023$ atau $\mathrm{p} \leq 0.05$, sehingga dapat disimpulkan bahwa iklim kerja memiliki pengaruh yang signifikan terhadap dehidrasi.

\section{Hubungan Beban Kerja dengan Dehidrasi}

Hasil penelitian menunjukkan, responden dengan beban kerja ringan yang mengalami dehidrasi ringan berjumlah 3 responden, 2 responden mengalami dehidrasi sedang, dan 2 responden mengalami dehidrasi berat. Responden dengan beban kerja sedang yang mengalami dehidrasi ringan berjumlah 2 responden, 3 responden mengalami dehidrasi sedang, dan 2 responden mengalami dehidrasi berat. Hasil uji Korelasi Spearman menunjukkan bahwa beban kerja tidak berhubungan dengan dehidrasi. Hal tersebut dapat disebabkan panas metabolisme tubuh yang tidak terlalu besar karena beban kerja responden yang cenderung ringan dan sedang.

Soeripto (2008) menjelaskan, panas metabolisme tubuh akan menurun jika beban kerja diturunkan, begitu pula sebaliknya. Kombinasi antara panas metabolisme dengan panas di lingkungan kerja menyebabkan tekanan panas (heat stress) sehingga responden dapat mengalami dehidrasi. Teori yang dikemukakan Soeripto (2008) tersebut membuktikan bahwa beban kerja yang berat mengakibatkan naiknya panas metabolisme dan menyebabkan dehidrasi yang semakin berat, namun masih terdapat 2 responden dengan beban kerja ringan yang mengalami dehidrasi berat. Hal tersebut tidak sesuai dengan teori, oleh karena itu dapat ditarik kesimpulan bahwa beban kerja yang rendah dan sedang pada responden dapat menyebabkan tidak adanya hubungan antara beban kerja dengan dehidrasi.

Penelitian Margiasih (2016) pada pekerja penempa besi di sentra industri pande besi Desa Padas Kecamatan Karanganom Kabupaten Klaten, menunjukkan bahwa terdapat hubungan antara beban kerja dengan dehidrasi. Pengukuran beban kerja menggunakan metode \% CVL menunjukkan $75 \%$ pekerja termasuk dalam kategori beban kerja sedang, dan $25 \%$ termasuk dalam kategori beban kerja agak berat. Sebanyak 3,1\% pekerja mengalami dehidrasi ringan, $84,4 \%$ mengalami dehidrasi sedang, dan $12,5 \%$ mengalami dehidrasi berat. Analisis statistik menggunakan uji Pearson Product Moment ( $\alpha=5 \%$ ) menunjukkan nilai $\mathrm{p}=0,016(\mathrm{p}<\alpha)$ yang berarti tingkat \% CVL berhubungan dengan dehidrasi. Nilai $r=0,423$ menunjukkan hubungan tersebut bersifat sedang. Hasil penelitian tersebut membuktikan, terdapatnya hubungan antar variabel disebabkan karena beban kerja pada responden yang sedang dan berat sehingga meningkatkan penguapan melalui keringat. keringat yang keluar secara berlebihan dapat mengakibatkan gangguan keseimbangan caran tubuh, sehingga responden mengalami dehidrasi.

\section{Hubungan Konsumsi Air Minum dengan Dehidrasi}

Hasil penelitian yang telah dilakukan menunjukkan terdapat 3 responden dengan konsumsi air minum cukup yang mengalami dehidrasi ringan. 
Responden dengan konsumsi air minum kurang yang mengalami dehidrasi sedang sebanyak 4 responden, dan 2 responden mengalami dehidrasi berat. Hasil analisis statistik dengan uji Korelasi Spearman menunjukkan konsumsi air minum memiliki hubungan yang sangat kuat dengan dehidrasi. Hal tersebut sesuai dengan pernyataan Armstrong (2007), yaitu waktu dan volume ketika mengonsumsi air minum berhubungan dengan dehidrasi. Seseorang yang mengonsumsi air sesuai dengan kebutuhan tubuh maka air akan memasuki darah dan ginjal sehingga urin yang dihasilkan tubuh berwarna cerah, sebaliknya urin akan berwarna pekat ketika seseorang mengonsumsi air minum dalam jumlah yang kurang. Semakin pekat warna urin maka tingkat dehidrasi semakin meningkat.

Penelitian Andayani (2013) membuktikan adanya hubungan antara konsumsi cairan dengan status hidrasi pada pekerja PT. Komatsu Indonesia. Hasil pengukuran konsumsi cairan menunjukkan 2,7\% pekerja mengonsumsi 6-7,9 liter air per hari, $53,4 \%$ pekerja mengonsumsi $4,0-5,9$ liter air per hari, dan 43,9\% pekerja mengonsumsi 2,0-3,9 liter air per hari. Pengukuran status hidrasi menggunakan metode berat jenis urin (BJU) menunjukkan pekerja yang memiliki status hidrasi yang baik hanya sebesar $28,8 \%$, sedangkan $52 \%$ pekerja mengalami pre-dehidrasi $(37,0 \%$ pekerja mengalami dehidrasi ringan dan $15 \%$ pekerja mengalami dehidrasi sedang), dan 19,2\% pekerja mengalami dehidrasi. Hasil analisis statistik menggunakan uji rank Spearman menunjukkan nilai $\mathrm{r}=-0,319$ dan $p$ $=0,006$ yang artinya terdapat hubungan negatif antara konsumsi cairan dengan status hidrasi. Hasil penelitian tersebut membuktikan bahwa semakin tinggi konsumsi cairan pada pekerja maka semakin rendah nilai berat jenis urin yang berarti semakin baik status hidrasi.

Konsumsi air minum dalam jumlah yang kurang pada responden juga dapat menyebabkan heat cramp. Suma'mur (2009) menjelaskan, pekerjaan yang dilakukan di tempat dengan suhu ruangan panas menyebabkan keluarnya keringat dalam jumlah yang banyak sehingga tubuh akan kehilangan garam natrium. Hasil wawancara awal dengan responden menunjukkan, keluhan yang biasa diderita responden saat bekerja yaitu nyeri pada lengan dan pundak. Hal tersebut sesuai dengan salah satu gejala heat cramp yaitu nyeri pada otot lengan, kaki atau perut akibat kontraksi mendadak. Responden sebaiknya mengonsumsi air minum yang diberi tambahan garam atau mengonsumsi makanan yang banyak mengandung natrium untuk mengganti garam natrium yang hilang ketika berkeringat sehingga heat cramp dapat dicegah.

\section{SIMPULAN}

Hasil penelitian yang telah dilakukan pada pekerja di Pabrik Tahu UD Sumber Kencana menunjukkan, beban kerja pada pekerja hanya termasuk dalam dua kategori saja yaitu beban kerja ringan $(50 \%)$ dan sedang $(50 \%)$. Hasil tersebut menunjukkan tidak terdapat pekerja dengan beban kerja berat, sangat berat, dan sangat berat sekali. Mayoritas pekerja (64,29\%) mengonsumsi air minum dalam jumlah kurang dari 1.800-2.400 cc selama 4 jam kerja sehingga termasuk dalam kategori kurang, sedangkan pekerja yang lain $(35,71 \%)$ mengonsumsi air minum dalam jumlah yang cukup yaitu antara 1.800-2.400 cc selama 4 jam kerja. Tidak terdapat pekerja yang mengonsumsi air minum dalam jumlah yang lebih. Pengukuran dehidrasi pada pekerja menunjukkan hasil yaitu sebanyak $35,71 \%$ pekerja mengalami dehidrasi ringan, $35,71 \%$ pekerja mengalami dehidrasi sedang, dan 28,58\% pekerja mengalami dehidrasi berat. Analisis menggunakan uji Korelasi Spearman menunjukkan, beban kerja pada pekerja di Pabrik Tahu UD Sumber Kencana memiliki hubungan yang sangat lemah dengan dehidrasi pekerja, dengan nilai koefisien korelasi (r) sebesar 0,094. Konsumsi air minum pada pekerja di Pabrik Tahu UD Sumber Kencana memiliki hubungan yang sangat kuat dengan tingkat dehidrasi pekerja, dengan nilai koefisien korelasi (r) sebesar 0,882 .

Analisis statistik yang telah dilakukan menunjukkan bahwa konsumsi air minum berhubungan positif dengan dehidrasi pada pekerja di Pabrik Tahu UD Sumber Kencana. Hal tersebut berarti semakin kurangnya konsumsi air minum pada pekerja, maka dehidrasi akan semakin berat.

\section{DAFTAR PUSTAKA}

Andayani, K., 2013. Hubungan Konsumsi Cairan dengan Status Hidrasi pada Pekerja Industri Laki-Laki. Artikel Penelitian. Semarang: Fakultas Kedokteran Universitas Diponegoro Semarang

Armstrong, L.E., 2007. Assessing Hydration Status: The Elusive Gold Standard. Journal of the American College of Nutrition, [e-Journal] 26(5): pp. $575 \mathrm{~S}-584 \mathrm{~S}$

Armstrong, L. E., Maresh, C. M., Castellani, J. W., 
Bergeron, M. F., Kenefick, R. V., LaGasse, K. E., \& Riebe, D. 1994. Urinary Indicies of Hydration Status. Int. J. Sport Nutrition, [e-Jorunal] 4(3): pp. 265-269

Armstrong, L. E., Maresh, C. M., Castellani, J. W., Bergeron, M. F., Kenefick, R. V., LaGasse, K. E., \& Riebe, D., 1998. Urinary Indicies Uduring Dehydration, Exercise, and Rehydration. Int. J. Sport Nutrition, [e-Journal] 8(4): pp. 345-355

Fajrin, N., Naiem, F., dan Rahim, R., 2014. Faktor yang Berhubungan dengan Keluhan Kesehatan Akibat Tekanan Panas pada Pekerja Instalasi Laundry Rumah Sakit di Kota Makassar. Media Kesehatan Masyarakat Indonesia, pp. 1-11

Maharja, R., 2015. Analisis Tingkat Kelelahan Kerja berdasarkan Beban Kerja Fisik Perawat di Instalasi Rawat Inap RSU Haji Surabaya. The Indonesian Journal of Occupational Safety and Health, [e-Jurnal] 4 (1): pp. 93-102

Margiasih, O.A., 2016. Hubungan Beban Kardiovaskuler dengan Dehidrasi dan Kelelahan pada Pekerja Bagian Penempaan Besi di Sentra Industri Pande Besi Desa Padas Kecamatan Karanganom Kabupaten Klaten. Publikasi Ilmiah. Surakarta: Fakultas Ilmu Kesehatan Universitas Muhammadiyah Surakarta

NIOSH, 2011. Protecting Workers from Heat Illness. Washington D.C: NIOSH
Puspita, A. D., 2015. Iklim Kerja dan Beban Kerja terhadap Tingkat Dehidrasi Pekerja Shift Pagi Bagian Injection Moulding 1 PT. X Sidoarjo. Skripsi. Surabaya: Fakultas Kesehatan Masyarakat Universitas Airlangga

Sari, N. P., 2014. Pengaruh Iklim Kerja Panas terhadap Dehidrasi dan Kelelahan pada Tenaga Kerja Bagian Boiler di PT Albasia Sejahtera Mandiri Kabupaten Semarang. Skripsi. Solo: Fakultas Ilmu Kesehatan Universitas Muhammadiyah Surakarta

Sherwood, L.I., 2011. Fisiologi Manusia. Jakarta: EGC

Soedirman, Suma'mur, P.K., 2014. Kesehatan Kerja dalam Perspektif Hiperkes \& Keselamatan Kerja. Jakarta: Penerbit Erlangga

Soeripto, M., 2008. Higiene Industri. Jakarta: Balai Penerbit FKUI

Suma'mur, P. K., 2009. Higiene Perusahaan dan Keselamatan Kerja. Jakarta: CV Haji Mas Agung

Tarwaka, Solichul, H., Bakri, A., dan Sudiajeng, L., 2004. Ergonomi-untuk Keselamatan, Kesehatan Kerja \& Produktivitas. Jakarta: Penerbit Buku Kedokteran

Undang-Undang Republik Indonesia Nomor 13 Tahun 2003 Tentang Ketenagakerjaan. Jakarta: DPR RI 